\title{
Annual litterfall dynamics and nutrient deposition depending on elevation and land use at Mt. Kilimanjaro
}

\author{
J. Becker ${ }^{1}$, H. Pabst ${ }^{1}$, J. Mnyonga ${ }^{2}$, and Y. Kuzyakov ${ }^{1,3}$ \\ ${ }^{1}$ Department of Soil Science of Temperate Ecosystems, University of Göttingen, Göttingen, Germany \\ ${ }^{2}$ Department of Forest Biology, Sokoine University of Agriculture, Morogoro, Tanzania \\ ${ }^{3}$ Department of Agricultural Soil Science, University of Göttingen, Göttingen, Germany
}

Correspondence to: J. Becker (joscha.becker@gmx.de)

Received: 2 June 2015 - Published in Biogeosciences Discuss.: 7 July 2015

Accepted: 6 September 2015 - Published: 7 October 2015

\begin{abstract}
Litterfall is one of the major pathways connecting above- and below-ground processes. The effects of climate and land-use change on carbon (C) and nutrient inputs by litterfall are poorly known. We quantified and analyzed annual patterns of $\mathrm{C}$ and nutrient deposition via litterfall in natural forests and agroforestry systems along the unique elevation gradient of Mt. Kilimanjaro.

Tree litter in three natural (lower montane, Ocotea and Podocarpus forests), two sustainably used (homegardens) and one intensively managed (shaded coffee plantation) ecosystems was collected on a biweekly basis from May 2012 to July 2013. Leaves, branches and remaining residues were separated and analyzed for $\mathrm{C}$ and nutrient contents.

The annual pattern of litterfall was closely related to rainfall seasonality, exhibiting a large peak towards the end of the dry season (August-October). This peak decreased at higher elevations with decreasing rainfall seasonality. Macronutrients $(\mathrm{N}, \mathrm{P}, \mathrm{K})$ in leaf litter increased at mid elevation (2100 m a.s.l.) and with land-use intensity. Carbon content and micronutrients ( $\mathrm{Al}, \mathrm{Fe}, \mathrm{Mn}, \mathrm{Na}$ ) however, were unaffected or decreased with land-use intensity.

While leaf litterfall decreased with elevation, total annual input was independent of climate. Compared to natural forests, the nutrient cycles in agroforestry ecosystems were accelerated by fertilization and the associated changes in dominant tree species.
\end{abstract}

\section{Introduction}

With their high biodiversity and importance for the global carbon (C) cycle, tropical forests are often highlighted as ecosystems of specific research interest (Brown, 1993; Sayer et al., 2011). Tropical forest ecosystems account for one third of the terrestrial net primary production (NPP) (Saugier et al., 2001) and contain more than half of the world's terrestrial species (Groombridge and Jenkins, 2002). Tropical forests also act as a net sink for $\mathrm{CO}_{2}(\mathrm{FAO}, 2010)$ and contain roughly $25 \%$ of the terrestrial biosphere $\mathrm{C}$ (Bonan, 2008).

Tree litterfall is one of the major pathways in $\mathrm{C}$ and nutrient cycles that connect above- and below-ground processes (Vitousek and Sanford, 1986). As an important and regular source of nutrients and organic matter, litterfall has been well studied over the past few decades (Vitousek, 1984; Meier et al., 2005; Carnol and Bazgir, 2013). Nonetheless, litterfall varies considerably between ecosystems, depending on climate, tree species composition, stand structure and soil fertility (Vitousek and Sanford, 1986). Elevation is strongly affecting these parameters in montane ecosystems (Ensslin et al., 2015; Pabst et al., 2013) and is of particular importance regarding potential ecosystem shifts through climate change (Beniston, 2003). Therefore, the effect of elevation on litterfall is an important indicator for estimating future changes in ecosystem cycles.

Land-use change affects numerous biological, chemical and physical factors as well as their interactions, leading to a high complexity and unpredictability of anthropogenic effects on ecosystem functions (Groffman et al., 2001). Especially the functioning of $\mathrm{C}$ and nutrient cycles under natural 
and disturbed conditions is important to assess the overall impact of anthropogenic land use on tropical forest ecosystems. As reviewed by Don et al. (2011), soil organic matter decreases up to $30 \%$ by converting tropical forests to agricultural systems. These effects might still be underrepresented in estimates of overall ecosystem C fluxes (de Blécourt et al., 2013).

This underrepresentation is particularly relevant because deforestation and conversion to intensive agriculture are common transformations in tropical regions and are projected to remain a major issue in the future (Lewis, 2006). Between 2000 and 2005, forest cover in Africa decreased by 11.5 million ha (Hansen et al., 2010) and this number is feared to increase further (UCS, 2011). The deforestation rate in Tanzania, for example, is already one of the largest in Africa (Fisher, 2010). In contrast to other tropical regions, it is mainly driven by small-scale farming for regional food production. Moreover, there was a considerable intensification of agricultural land use at Mt. Kilimanjaro within the last 50 years (Misana et al., 2012).

Most of the recent research on nutrient cycling in tropical forest ecosystems has been conducted in the Neotropics and Southeast Asia (Zhou et al., 2006; Chave et al., 2010; Celentano et al., 2011; González-Rodríguez et al., 2011; Fontes et al., 2014; Vasconcelos et al., 2008), while African forests, especially montane rainforests in East Africa, have received much less attention (Schrumpf et al., 2006; Dawoe et al., 2010). Mt. Kilimanjaro offers the possibility to investigate nutrients cycles and litterfall along an elevation gradient where soils have a similar age and developed from the same parent material (Dawson, 1992). We are aware of only one study that published data on nutrient cycling with partial focus on litterfall in Mt. Kilimanjaro ecosystems (Schrumpf et al., 2006). Various studies in other ecosystems have shown that artificial nutrient addition accelerate nutrient cycles (Allison and Vitousek, 2004; Forrester et al., 2005; Homeier et al., 2012). It remains unclear how agricultural land use affects nutrient balances and its interrelation to litter quantity, quality and the above- and belowground element cycles in tropical (agro)ecosystems.

Our primary objective was to assess the effect of climate and of agricultural land use on litterfall and nutrient and carbon cycles in the dominant ecosystems of Mt. Kilimanjaro. Therefore, we (1) collected the annual litter deposition and examined the litterfall dynamics throughout the year, (2) measured the annual $\mathrm{C}$ and nutrient return and (3) compared differences between natural and managed ecosystems and address implications for the ecosystem nutrient cycle.

\section{Methods}

\subsection{Study site}

The study was conducted on the southwestern slope of Mt. Kilimanjaro ( $\left.3^{\circ} 4^{\prime} 33^{\prime \prime} \mathrm{S}, 37^{\circ} 21^{\prime} 12^{\prime \prime} \mathrm{E}\right)$, Tanzania, along an elevation gradient from 1275 to 2850 ma.s.l. Our study was part of the German Research Foundation Project: Kilimanjaro ecosystems under global change. This interdisciplinary project provided a number of long-term research locations, plots, data and facilities along the southwestern slope of Mt. Kilimanjaro. Six research sites were selected according to the joint study design. Each is representing either a typical tropical montane forest zone or a representative land-use class of the region (Table 1). Lower montane forest (FLM), Ocotea forest (FOC) and Podocarpus forest (FPO) are three natural sites located in Kilimanjaro National Park with minor anthropogenic impact. Nonetheless, illegal logging for firewood and building material may occur, especially in the lower FLM areas (Lambrechts et al., 2002; Rutten et al., 2015). The vegetation and zonation of these ecosystems was classified and described in detail by Hemp (2006a). Summarily, FLM is dominated by Macaranga kilimandscharica, Agauria salicifolia and partly Ocotea usambarensis, while at higher elevation Ocotea usambarensis prevails, accompanied by Cyathea manniana (FOC). The forest above $2800 \mathrm{~m}$ a.s.l. is dominated by Podocarpus latifolius together with Prunus africana and Hagenia abyssinica (FPO). Two Chagga homegardens (HOMa, $\mathrm{HOMb}$ ) represent a traditional form of sustainably managed agroforestry with sporadic organic fertilization with manure and household waste (Fernandes et al., 1986). Homegardens are multilayered agroforestry systems with Musa ssp. and Coffea ssp. as dominant crops under remnant forest trees (e.g. Albizia schimperiana, Cordia africana) and cultivated fruit trees (e.g. Persea Americana, Grevillea robusta) (Hemp, 2006b). Shaded coffee plantation (COF) represented an intensively managed land-use type with regular application of mineral fertilizers and pesticides. A detailed description of land-use history of Mt. Kilimanjaro was given by Pabst (2015) and further information on aboveground biomass and vegetation structure is available from Ensslin et al. (2015).

The climate at Mt. Kilimanjaro is characterized by a bimodal rainfall regime with a short rainy season around November and a longer one from March to May (Hemp, 2006a). Mean annual precipitation (MAP) varies depending on elevation and exposition between $1336 \mathrm{~mm}$ and about $3000 \mathrm{~mm}$ per year (Table 1). Mean annual temperature (MAT) ranges from 9.8 to $20.9^{\circ} \mathrm{C}$ and monthly means vary around $\pm 3{ }^{\circ} \mathrm{C}$.

The comparison of ecosystems and litterfall on Mt. Kilimanjaro is especially beneficial because the soils have a similar age and developed from similar parent material over the last 0.2 to 2.3 Mio years (Dawson, 1992). These parent materials are formed by volcanic rocks such as basalt, trachyte and 
Table 1. Land-use classification, topographic and climatic information and $\mathrm{C}$ and $\mathrm{N}$ stocks in $0-10 \mathrm{~cm}$ soil depth of research plots on the southern slope of Mt. Kilimanjaro.

\begin{tabular}{lllrrrrr}
\hline Ecosystem & Plot ID & Land-use class & $\begin{array}{r}\text { Elevation } \\
(\mathrm{m} \mathrm{a.s.1.})\end{array}$ & $\begin{array}{r}\text { MAP } \\
\left(\mathrm{mm} \mathrm{yr}^{-1}\right)^{\mathrm{a}}\end{array}$ & $\begin{array}{r}\text { MAT 2012 } \\
\left({ }^{\circ} \mathrm{C}\right)^{\mathrm{b}}\end{array}$ & $\begin{array}{r}\text { Soil C } \\
\left(\mathrm{mg} \mathrm{cm}^{-3}\right)^{\mathrm{c}}\end{array}$ & $\begin{array}{r}\text { Soil N } \\
\left(\mathrm{mg} \mathrm{cm}^{-3}\right)^{\mathrm{c}}\end{array}$ \\
\hline Chagga homegarden & HOMa & Agricultural, traditional & 1275 & 1336 & 20.9 & 24.7 & 2.1 \\
Coffee plantation & COF & Agricultural, intensive & 1305 & 1485 & 20.2 & 19.3 \\
Chagga homegarden & HOMb & Agricultural, traditional & 1647 & 2616 & 17.3 & 36.1 & 1.9 \\
Lower montane forest & FLM & Natural, disturbed & 1920 & 2378 & 15.3 & 45.8 \\
Ocotea forest & FOC & Natural & 2120 & 2998 & 11.2 & 55.8 \\
Podocarpus forest & FPO & Natural & 2850 & 1773 & 9.8 & 53.5 & 3.1 \\
\hline
\end{tabular}

a mean annual precipitation (Appelhans et al., 2014), ${ }^{\mathrm{b}}$ mean annual temperature in $2012,^{\mathrm{c}}$ stocks in $0-10 \mathrm{~cm}$ soil depth (calculated from Pabst et al., 2013).

olivine basalts. Soils are classified as Andosols with folic, histic or umbric topsoil horizons with accordingly high $\mathrm{C}$ contents in the upper horizons (Zech, 2006), often underlain by C-rich paleosol sequences (Zech et al., 2014). Water extractable and microbial biomass $\mathrm{C}$ increase with elevations and decrease with management intensity (Pabst et al., 2013).

\subsection{Sampling}

Within each ecosystem, 10 traps $\left(1 \mathrm{~m}^{2}, 1 \mathrm{~mm}\right.$ mesh size $)$ were installed as replicates along two $100 \mathrm{~m}$ transects $(5$ per transect). Due to the areal structure of one of the homegardens (HOMb), the number of litter traps had to be reduced and only five replicates could be installed. To exclude undergrowth, net heights were set between 20 and $100 \mathrm{~cm}$ above ground. Between April 2012 and July 2013, litter was collected twice a month.

Litter samples were oven-dried for 1 week at $60^{\circ} \mathrm{C}$ and then weighed. Within the 2 -week sampling interval the weight loss by decomposition was presumed negligible. Litter was manually sorted into leaves, branches $(<2 \mathrm{~cm}$ in diameter) and a rest fraction containing blossoms and fruits as well as unidentified materials. Wooden material $>2 \mathrm{~mm}$ is too persistent to be evaluated within the timescale of our study and was thus excluded from analysis. Leaf litter samples were coarsely ground and stored in paper bags for further analysis.

\subsection{Analyses of carbon and nutrient contents}

We expected leaves to contain most of the litter nutrients (Yang et al., 2004). Therefore, nutrient analyses were limited to the leaf fraction. Leaf litter samples were bulked randomly and divided into two subsamples from five nets per time step. Nutrient content of leaf litter was analyzed from six sampling dates equally distributed over 1 year. In line with Celentano et al. (2011), we refrained from seasonal subdivision because most nutrients show low seasonal variation. A total number of 12 samples per ecosystem were fine-ground and analyzed for $\mathrm{C}$ and nutrient contents. $\mathrm{C}$ and $\mathrm{N}$ contents were determined with a dry combustion automated $\mathrm{C}: \mathrm{N}$ analyzer
(Vario EL, Elementar). After a preparative pressure digestion, inductively coupled plasma optical emission spectrometry (ICP-OES, Spectro Analytical Instruments) was used to determine contents of major macro- $(\mathrm{Ca}, \mathrm{K}, \mathrm{Mg}, \mathrm{P}, \mathrm{S})$ and micro- (Al, Fe, Mn, Na) nutrients. All chemical analyses were conducted in the laboratory of the Department of Soil Science of Temperate Ecosystems, University of Göttingen.

\subsection{Calculations and statistical analyses}

Annual litter deposition per ecosystem was calculated as the average from nets over 1 year (June 2012 to May 2013). Monthly deposition rates were calculated assuming a constant amount per day for each sampling interval. For missing values we assumed a linear behavior of litterfall between the previous and the following date. Nutrient deposition was calculated as the product of annual leaf deposition and mean nutrient content.

As our data do not meet the requirements for ANOVA and non-normal distribution must be assumed (Shapiro-Wilk test, $p<0.05$ ), we applied non-parametric statistics. Significant differences were detected using the Kruskal-Wallis test with a Bonferroni correction at $p$ level $=0.05$ (Katz, 2006). The presented data are means of 5 to 10 replications \pm standard error (SE).

All statistical analyses were conducted in R 3.0.1 (R Core Team, 2013) using core and agricolae (de Mendiburu, 2014) packages as well as the ggplot2 package for data visualization (Wickham, 2009).

\section{Results}

\subsection{Annual amount of litterfall}

The annual amount of total litterfall was independent of land use and elevation, whereas the amount of leaf litter in natural forests decreased with elevation (Fig. 1). The total annual input varied from $4.6 \mathrm{Mg} \mathrm{ha}^{-1}$ in HOMa to $10.7 \mathrm{Mg} \mathrm{ha}^{-1}$ in $\mathrm{HOMb}$. Accordingly, HOMb had a significantly higher total litterfall than HOMa as well as FOC and FPO. 


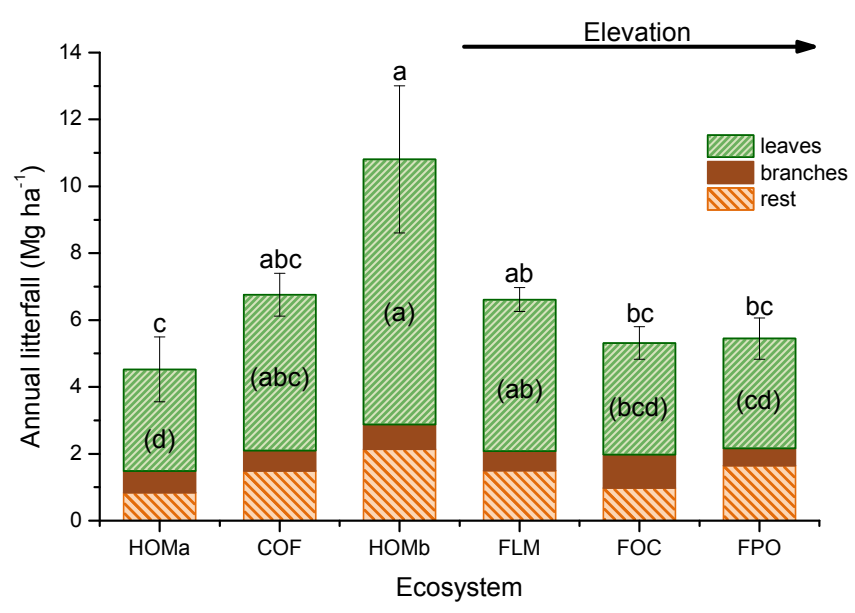

Figure 1. Annual litterfall and its components (2012 to 2013) in Chagga homegardens (HOMa and HOMb), shaded coffee plantation (COF), lower montane forest (FLM), Ocotea forest (FOC) and Podocarpus forest (FPO). Error bars indicate standard errors for total amount with significance levels shown as small letters a-c $(p \leq 0.05)$. Letters in brackets $(\mathrm{a}-\mathrm{d})$ indicate significance levels for leaf fraction only.

Total litterfall was dominated by the portion of leaves, contributing between $61 \%$ (FPO) and $74 \%$ (HOMb). The annual value in FLM was significantly higher than in FPO (Fig. 1). Deposition of branches and rest were on the same level for all sites: each constituted less than $30 \%$ of total litterfall.

\subsection{Seasonal dynamics of litterfall}

The seasonal patterns of litterfall were the same for natural and agroforestry systems if compared on the closest elevation level. In forests at higher elevation the seasonality was less pronounced and the peak values shifted from the end of the dry season towards the rainy season (Fig. 2).

Similar to the annual litterfall, changes in monthly litterfall were determined by the portion of leaves. Maximum values in homegardens, COF and FLM were recorded between the mid- and late dry season (Fig. 2). A second smaller peak appeared in the second rainy season around April. Within these peaks, monthly litterfall increased three- (HOMa) to ninefold (COF) in agroforestry systems. In natural forests, peaks increased about $350 \%$ in FLM, 300\% in FOC and $450 \%$ in FPO. In FOC and FPO the first peak was delayed until November or December and was extended because litterfall rates remained high in the short dry season between January and March. Litterfall maxima within the year were positively related to elevation (Fig. 3). Deposition patterns of branches were independent of seasons, and peaks occurred erratically (Fig. 2). The deposition of the rest fraction did not follow pronounced dynamics but the peaks tended to increase during the rainy seasons.

\subsection{Nutrient contents and deposition}

Agroforestry systems showed higher macronutrient content and deposition rates than natural forests (Table 2). With increasing elevation in the natural forests, nine of eleven analyzed nutrients followed a hump-shaped pattern with the highest content in FOC (2120 m a.s.l.) and lower contents in FLM (1920 m a.s.1.) and FPO (2850 m a.s.l.) (Appendix Table A1).

The N, P, and S contents in leaves under agricultural land use were significantly higher compared to those in natural forests (Fig. 4; Appendix). Potassium was enriched in the leaf litter of managed ecosystems ( 7.4 to $15.8 \mathrm{mg} \mathrm{g}^{-1}$ ) versus most natural forests ( 3.1 to $7.2 \mathrm{mg} \mathrm{g}^{-1}$ ). The contents of $\mathrm{C}, \mathrm{Al}, \mathrm{Mg}, \mathrm{Fe}$, and $\mathrm{Ca}$ were independent of land use. Due to the similar $\mathrm{C}$ and the increased $\mathrm{N}$ content, the $\mathrm{C}: \mathrm{N}$ ratio was significantly lower in managed ecosystems. It ranged from $16.9( \pm 0.6)$ to $20.4( \pm 0.6)$ in agroforestry systems and from $32.1( \pm 0.4)$ to $44.9( \pm 0.5)$ in natural forests. Na and Mn contents were lower under agricultural land use (Table 2).

The effect of land use on the annual nutrient deposition was buffered by the amount of litterfall, but remained present. HOMb had the highest $\mathrm{C}$ and nutrient deposition (except for $\mathrm{Mn}$ and $\mathrm{Na}$ ) via litterfall compared to all other ecosystems (Table 2). The coffee plantation also had significantly higher $\mathrm{N}, \mathrm{P}, \mathrm{K}, \mathrm{Fe}$, and $\mathrm{Ca}$ deposition than all natural forests. Due to minimal litterfall in HOMa the annual nutrient deposition was low despite high concentrations in leaves. The deposition of most macronutrients in HOMa was still higher or on the same level as in natural forests. The $\mathrm{Al}$ and $\mathrm{Na}$ deposition was unaffected by land-use intensity. Annual Mn deposition was significantly higher in natural forests than in managed sites.

\section{Discussion}

\subsection{Litterfall characteristics}

The amounts of litterfall in Mt. Kilimanjaro ecosystems were within the common range for tropical mountain forests and followed a pronounced seasonality dependent on climatic variations. The annual leaf litterfall $\left(4.6-10.7 \mathrm{Mg} \mathrm{ha}^{-1}\right)$ was also within the same range as at various other tropical sites (Chave et al., 2010; Zhang et al., 2014). A previous study at Mt. Kilimanjaro found similar amounts of fine litterfall $\left(7.5 \mathrm{Mg} \mathrm{ha}^{-1}\right)$ at an elevation of 2250 to $2350 \mathrm{~m}$ a.s.l. (Schrumpf et al., 2006). Lisanework and Michelsen (1994) reported annual fine litter production ranging from 5.0 to $6.5 \mathrm{Mg} \mathrm{ha}^{-1}$ in tree plantations and $10.9 \mathrm{Mg} \mathrm{ha}^{-1}$ in a natural forest in the Ethiopian highlands. Similar results were found for cacao plantations in lowland humid Ghana where total litter ranged from 5.0 to $10.4 \mathrm{Mg} \mathrm{ha}^{-1}$ (Dawoe et al., 2010). The portion of leaf litter commonly varies between 60 and $90 \%$ (Lisanework and Michelsen, 1994; Schrumpf 

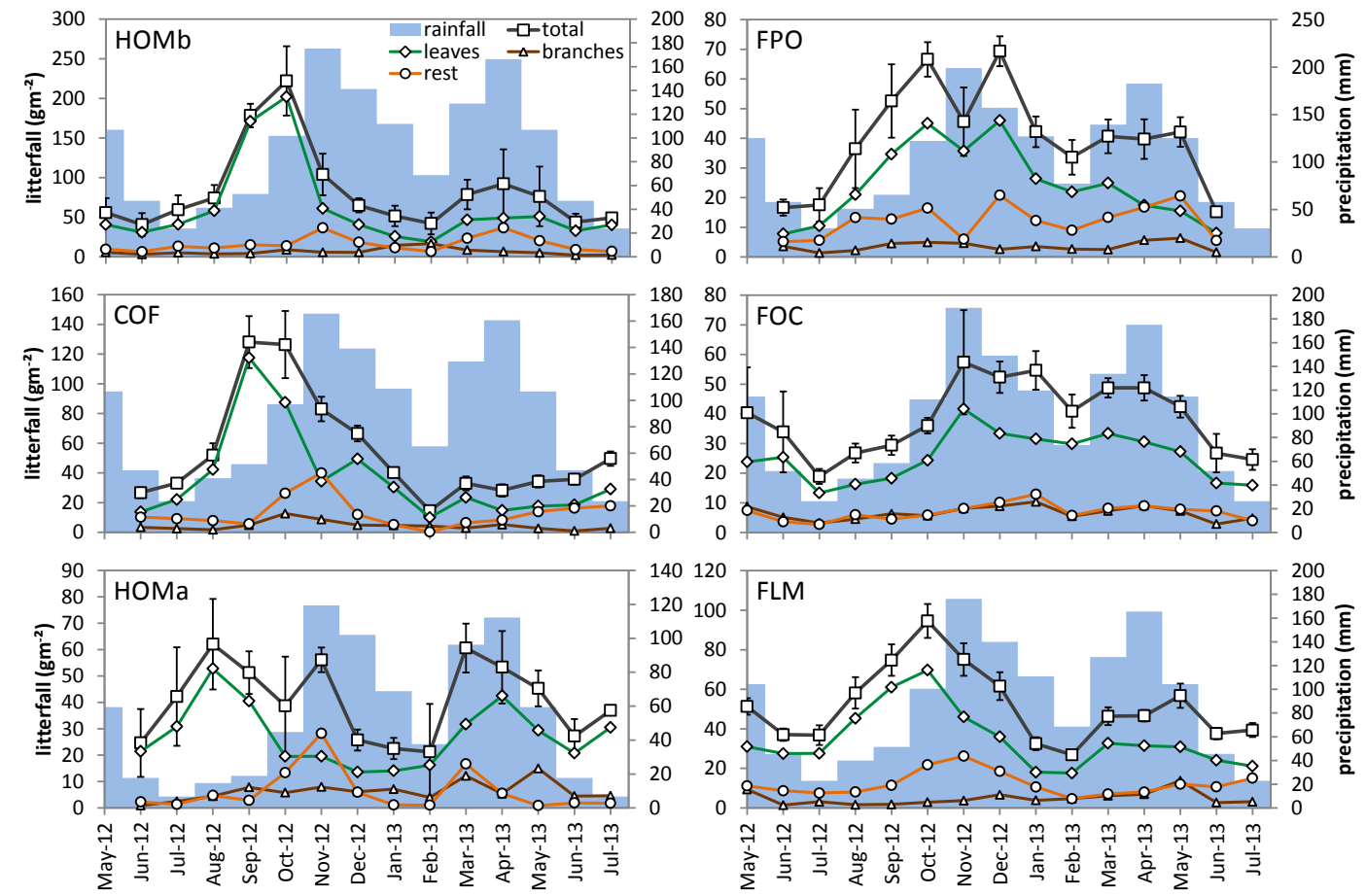

Figure 2. Monthly litterfall from May 2012 to July 2013 in Chagga homegardens (HOM), shaded coffee plantation (COF), lower montane forest (FLM), Ocotea forest (FOC) and Podocarpus forest (FPO). Total litterfall (squares) is divided into leaves (diamonds), branches (triangles) and rest (circles). Ten-year mean of monthly precipitation (2000 to 2010, TRMM, http://pmm.nasa.gov) is indicated as bars. Standard errors (SE) are displayed by error bars.

Table 2. Annual nutrient deposition via leaf litterfall (Mean $\pm \mathrm{SE}, \mathrm{kg} \mathrm{ha}^{-1} \mathrm{yr}^{-1}$ ) from six ecosystems at Mt. Kilimanjaro. Superscript letters indicate significant differences between sites (Kruskal-Wallis Test; $p$ level $\leq 0.05$ ).

\begin{tabular}{|c|c|c|c|c|c|c|}
\hline$\left(\mathrm{kg} \mathrm{ha}^{-1} \mathrm{yr}^{-1}\right)$ & HOMa & $\mathrm{COF}$ & $\mathrm{HOMb}$ & FLM & FOC & FPO \\
\hline $\mathrm{C}$ & $1454.1 \pm 294.5^{\mathrm{c}}$ & $2230.8 \pm 160.4^{\mathrm{ab}}$ & $3948.2 \pm 606.8^{\mathrm{a}}$ & $2169.1 \pm 71.1^{\mathrm{ab}}$ & $1635.7 \pm 134.1^{b c}$ & $1600.8 \pm 176.2^{b c}$ \\
\hline $\mathrm{N}$ & $87.0 \pm 17.6^{\mathrm{bc}}$ & $110.3 \pm 7.9^{\mathrm{ab}}$ & $233.5 \pm 35.9^{\mathrm{a}}$ & $48.7 \pm 1.6^{\mathrm{cd}}$ & $51.9 \pm 4.3^{\mathrm{cd}}$ & $38.2 \pm 4.2^{\mathrm{d}}$ \\
\hline $\mathrm{Al}$ & $2.9 \pm 0.6^{\mathrm{b}}$ & $5.1 \pm 0.4^{\mathrm{a}}$ & $6.1 \pm 0.9^{\mathrm{a}}$ & $1.9 \pm 0.1^{b}$ & $4.5 \pm 0.4^{\mathrm{a}}$ & $2.4 \pm 0.3^{b}$ \\
\hline $\mathrm{Ca}$ & $54.6 \pm 11.1^{\mathrm{ab}}$ & $63.5 \pm 4.6^{\mathrm{a}}$ & $63.0 \pm 9.7^{\mathrm{a}}$ & $30.0 \pm 1.0^{\mathrm{c}}$ & $33.6 \pm 2.8 \mathrm{a}^{\mathrm{b}}$ & $29.8 \pm 3.3^{\mathrm{c}}$ \\
\hline $\mathrm{Fe}$ & $3.4 \pm 0.7^{\mathrm{abc}}$ & $3.8 \pm 0.3^{\mathrm{ab}}$ & $5.2 \pm 0.8^{\mathrm{a}}$ & $1.3 \pm 0.0^{\mathrm{d}}$ & $2.6 \pm 0.2^{b c}$ & $2.4 \pm 0.3^{\mathrm{c}}$ \\
\hline K & $22.6 \pm 4.6^{\mathrm{b}}$ & $59.9 \pm 4.3^{\mathrm{a}}$ & $125.4 \pm 19.3^{\mathrm{a}}$ & $14.0 \pm 0.5^{\mathrm{c}}$ & $13.0 \pm 1.1^{\mathrm{c}}$ & $23.6 \pm 2.6^{\mathrm{b}}$ \\
\hline $\mathrm{Mg}$ & $12.2 \pm 2.5^{\mathrm{ab}}$ & $9.9 \pm 0.7^{\mathrm{ab}}$ & $15.8 \pm 2.4^{\mathrm{a}}$ & $8.4 \pm 0.3^{\mathrm{bc}}$ & $9.0 \pm 0.7^{b}$ & $4.8 \pm 0.5^{\mathrm{c}}$ \\
\hline $\mathrm{Mn}$ & $0.4 \pm 0.1^{\mathrm{c}}$ & $1.0 \pm 0.1^{\mathrm{bc}}$ & $0.9 \pm 0.1^{\mathrm{bc}}$ & $2.3 \pm 0.1^{\mathrm{a}}$ & $2.2 \pm 0.2^{\mathrm{a}}$ & $2.7 \pm 0.3^{\mathrm{a}}$ \\
\hline $\mathrm{Na}$ & $0.5 \pm 0.1^{\mathrm{c}}$ & $1.0 \pm 0.1^{\mathrm{b}}$ & $1.7 \pm 0.3^{\mathrm{a}}$ & $1.9 \pm 0.1^{\mathrm{a}}$ & $2.0 \pm 0.2^{\mathrm{a}}$ & $0.7 \pm 0.1^{b c}$ \\
\hline $\mathrm{P}$ & $5.2 \pm 1.1^{\mathrm{ab}}$ & $5.3 \pm 0.4^{b c}$ & $10.9 \pm 1.7^{\mathrm{a}}$ & $3.0 \pm 0.1^{\mathrm{cd}}$ & $2.6 \pm 0.2^{\mathrm{d}}$ & $2.4 \pm 0.3^{\mathrm{d}}$ \\
\hline S & $5.2 \pm 1.0^{\mathrm{b}}$ & $7.4 \pm 0.5^{\mathrm{a}}$ & $15.7 \pm 2.4^{\mathrm{a}}$ & $4.8 \pm 0.2^{\mathrm{b}}$ & $4.0 \pm 0.3^{b c}$ & $2.9 \pm 0.3^{b c}$ \\
\hline
\end{tabular}

et al., 2006; Zhou et al., 2006; González-Rodríguez et al., 2011). Accordingly, leaf portions in Mt. Kilimanjaro litterfall $(60-75 \%)$ were at the lower end of tropical forest values.

The factors affecting litterfall amounts are succession stage, tree age and dominant plant or tree species (Barlow et al., 2007; Celentano et al., 2011). Varying management practices and crops in homegardens may alter these factors. The heterogeneity of the traditional agroforestry systems explains the low annual litterfall in HOMa. Compared to HOMb, there were more banana plants (Musa ssp.) in HOMa, which were manually cut as a management practice and thus were not accounted for by our litter traps.

Litterfall peaks during the dry season are well-documented in tropical forests and plantation systems and mainly reflect drought stress (Okeke and Omaliko, 1994; Barlow et al., 2007; Selva et al., 2007). A recent meta-analysis by Zhang et al. (2014) has shown that this connection is a characteristic feature of tropical ecosystems. Leaf aging, caused by 


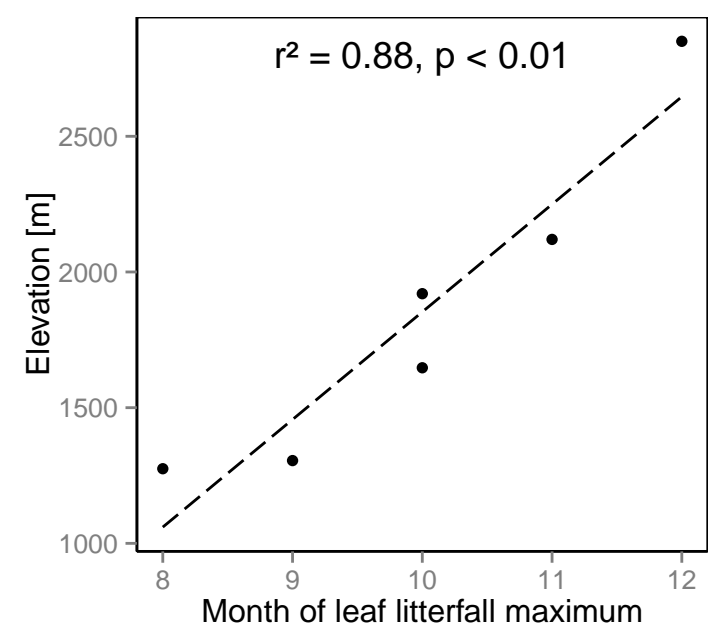

Figure 3. Linear regression between elevation and month of highest leaf litterfall in six ecosystems of Mt. Kilimanjaro.

photoinhibition, stomatal closure and subsequent leaf overheating, might lead to leaf shedding at the end of the dry season (Röderstein et al., 2005). As a side effect, trees are preparing for the upcoming season of highest net primary production. By contrast, the peaks during the rainy season are the result of strong winds and thunderstorms (Dawoe et al., 2010; González-Rodríguez et al., 2011). This explains the observed increase in peaks of branch and rest deposition during wet months.

\subsection{Effects of elevation}

The Mt. Kilimanjaro forest ecosystems are characterized by the absence of a pronounced trend of total annual litterfall with elevation. When the leaf fraction was compared separately though, the annual deposition was significantly higher in FLM than in higher forests (FOC, FPO) (Fig. 1). Leaf litter production is considered to depend on temperature and thus decreases at higher elevations (Okeke and Omaliko, 1994; Zhou et al., 2006; Girardin et al., 2010). Nonetheless, a series of other studies from various ecosystems also show no decrease with elevation (Röderstein et al., 2005; Köhler et al., 2008). Within our elevation range of $\sim 900 \mathrm{~m}$ in natural forests, the percentages of leaf litterfall were too small to determine a notable decrease of total litterfall with elevation. Sporadic sampling at higher elevations (data not shown) indicated that a litterfall decrease would become apparent in ecosystems above $3000 \mathrm{~m}$ a.s.l.

Seasonal variability of leaf litterfall in the natural forests on Mt. Kilimanjaro followed a U-shaped pattern with increasing elevation (Fig. 2). In tropical montane forests, the seasonality of litterfall is generally low compared to tropical lowland forests (Chave et al., 2010). We observed the weakest seasonal variation in Ocotea forest in $2190 \mathrm{~m}$ a.s.l., featuring the highest annual precipitation and least varying soil
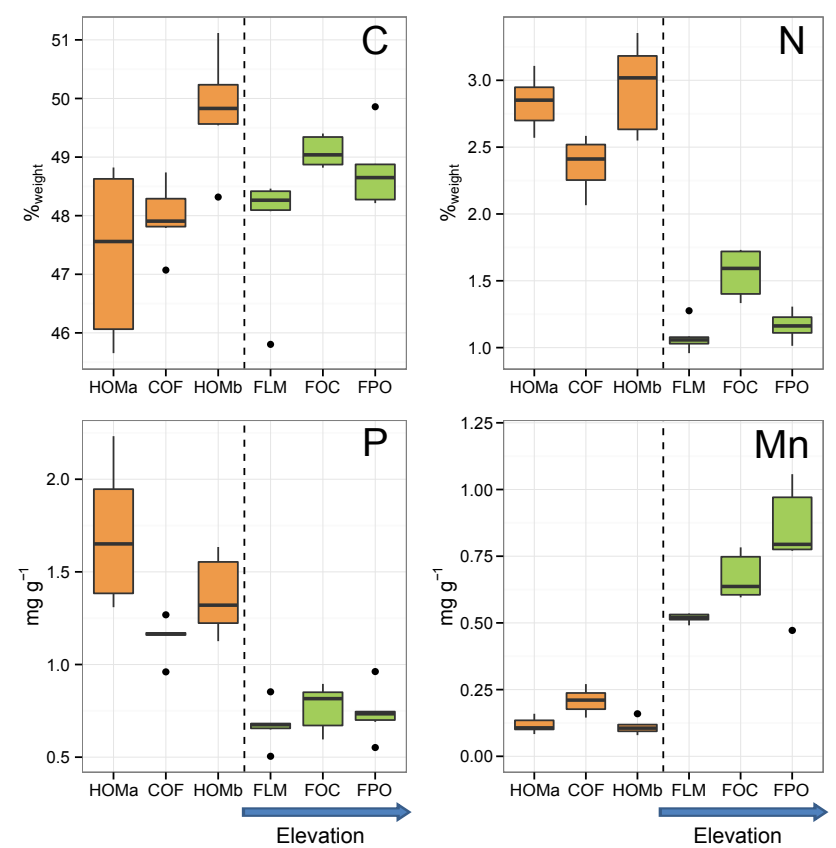

Figure 4. Contents of selected elements (C, N, P, Mn) in leaf litter from six ecosystems at Mt. Kilimanjaro. Medians, interquartile distances and extreme values are displayed as bold lines, boxes with whiskers and dots, respectively. Managed (left) and natural (right) ecosystems are separated by dashed line.

moisture conditions (Table 1). At FPO (2850 m a.s.1.) seasonality increased again with lower MAP and an increasing temperature limitation. Litter production at higher elevation was distributed over the warmer period between October and May when canopy productivity is usually higher (Girardin et al., 2010). This pattern is based on the dependency of litterfall seasonality on rainfall intensities as well as temperatures (Zhou et al., 2006; Chave et al., 2010). Changes of seasonality patterns occurred within a $200 \mathrm{~m}$ elevation difference (FLM to FOC). This suggests that elevation effects can easily overlay biome specific litterfall patterns and can contribute to the explanation of variabilities in large-scale data (Zhang et al., 2014).

We found no consistent effect of elevation on litter nutrient content within the agroforestry systems (Appendix Table A1). This indicates a strong overlay of elevation effects by land-use practices. This enables discussing the changes in contents along an elevation gradient only by comparing natural forests with each other. Carbon and most nutrient contents in leaf litter followed a hump-shaped pattern with elevation. This pattern is typical for other ecosystem properties along montane elevation gradients (Kluge et al., 2006; Mölg et al., 2009). It is also present for MAP at Mt. Kilimanjaro (Table 1) as well as for aboveground biomass (Ensslin et al., 2015). Pabst et al. (2013) reported hump-shaped soil moisture curves and mirroring patterns for soil $\mathrm{pH}$ from the same Kilimanjaro ecosystems. Both parameters control soil nutri- 
ent availability and they are without a doubt also key factors for variations of nutrient uptake by plants and consequently for the litter nutrient contents.

\subsection{Effects of land use}

The contents of most macronutrients in leaf litter of managed ecosystems were two to five times higher than in natural forests. This suggests that the chemical composition of leaf litter at Mt. Kilimanjaro was significantly altered by land use and the associated change of dominant plant or tree species.

Especially for studying land-use effects it can be difficult to find adequate and comparable sites. At Mt. Kilimanjaro there is nearly no natural forest below and no land use above $1800 \mathrm{~m}$ a.s.l. Given this limitation to our study design we will only discuss land-use effects that are significant when compared on the closest elevation levels (FLM and HOMb). According to Hemp (2006a) Mt. Kilimanjaro exhibits a strong ecological zonation. FLM and HOMb are both located in the same altitudinal zone (i.e. lower montane) and were selected to represent the respective zone of natural species composition (Ensslin et al., 2015). Therefore, we assume low elevation related variability. This assumption is also supported by the similar litter peak seasonality in both ecosystems (Fig. 3). Several studies from the tropics focus on nutrient contents in leaf litter of agricultural plantations (Beer, 1988; Dawoe et al., 2010), tree plantations (Sharma and Pande, 1989; Carnol and Bazgir, 2013) and natural forests (Dent et al., 2006; Lu and Liu, 2012). Some studies also compared tree plantations to natural forests (Lisanework and Michelsen, 1994; Celentano et al., 2011). However, the results vary considerably between study sites and are not directly comparable to each other. For example, the $\mathrm{N}$ content in litter is higher in Ethiopian natural forests than in tree plantations (Lisanework and Michelsen, 1994), while the opposite results were recorded from Costa Rican sites (Celentano et al., 2011). Independent from elevation, HOM and COF at Mt. Kilimanjaro had higher $\mathrm{N}$ contents and therefore lower $\mathrm{C}: \mathrm{N}$ ratios in leaf litter than natural forests (Fig. 4). Nitrogen is a limiting factor in tropical montane forests (Vitousek, 1984; Fisher et al., 2013), and N-deprived plants usually have a high $\mathrm{C}: \mathrm{N}$ ratio in litter (Chave et al., 2010). We expect two processes to mitigate the natural $\mathrm{N}$ limitation. First, the introduction of crops such as Musa ssp. and Coffea ssp. affects the nutrient content of vegetation and litter in general. Second, fertilization leads to higher $\mathrm{N}$ contents in plants and consequently in leaf litter (O'Connell and Grove, 1993). As a result the annual $\mathrm{N}$ deposition by litterfall in $\mathrm{HOM}$ and $\mathrm{COF}$ increased and $\mathrm{N}$ cycling in these ecosystems was enhanced. This is well in line with Zech et al. (2011), who found evidence for accelerated N-cycling in the cultivated areas of Mt. Kilimanjaro. Fertilization with $\mathrm{N}$ and $\mathrm{P}$ also increases the content of other macronutrients in leaf litter (O'Connell and Grove, 1993). This corresponds to our findings because the content of most macronutrients in land-use ecosystems either increased or remained on the same level compared to the natural forests. Specific micronutrient fertilization can be ruled out in homegardens (Fernandes et al., 1986). Consequently, micronutrients were either unaffected $(\mathrm{Al}, \mathrm{Fe})$ or decreased under managed conditions ( $\mathrm{Mn}, \mathrm{Na}$ ).

\subsection{Implications for ecosystem cycles}

The effects of land use and elevation on litterfall and nutrient contents also lead to two specific implications for $\mathrm{C}$ and nutrient cycles at the ecosystem level. The first implication can be drawn from the seasonal dynamics of litterfall. Litterfall peaks at the end of the dry season promote an accumulation of particulate organic matter on the surface soil. This accumulation entails increased microbial activity and mobilization of $\mathrm{C}$ and nutrients during the following wet season (Sayer et al., 2007; Blagodatskaya et al., 2009). Several studies reported a peak in freshly mobilized $\mathrm{C}$ and nutrients in the early wet season, increasing the possibility of leaching or translocation to deeper soil layers (Qiu et al., 2005; Pabst et al., 2013). As a consequence, an increased nutrient deposition via litterfall might not necessarily result in higher nutrient availability, but may actually increase nutrient losses. The investigated agricultural ecosystems at Mt. Kilimanjaro experience distinct climatic seasonality and accumulate large amounts of litter at the end of dry season. This implies that the nutrient cycles in these ecosystems are especially vulnerable to changes in vegetation structure and species composition.

The altered nutrient deposition rates lead to the second implication regarding turnover rates and $\mathrm{C}$ losses from soils. There is ambiguous information on the effects of single nutrient addition and fertilization on the decomposition rates of leaf litter (Khan et al., 2007; Grandy et al., 2013). While $\mathrm{N}$ or $\mathrm{P}$ addition alone might delay nutrient mobilization, decomposition is generally accelerated by a higher macronutrient content (Allison and Vitousek, 2004; Debusk and Reddy, 2005). In addition, Debusk and Reddy (2005) postulated that this acceleration is independent of soil nutrient content. The abundant macronutrients in the litter of the investigated agricultural ecosystems therefore imply an accelerated $\mathrm{C}$ and nutrient turnover in the respective ecosystems. Easily available substrate is decomposed faster, and soil respiration (i.e. soil $\mathrm{CO}_{2}$ efflux) is generally higher in soils of intensively managed versus natural ecosystems at Mt. Kilimanjaro (Mganga and Kuzyakov, 2014). Together with tillage and crop removal, this explains the lower $\mathrm{C}$ and $\mathrm{N}$ stocks in the topsoil of agroforestry systems compared to natural forests at Mt. Kilimanjaro (Table 1). As a consequence, the conversion of natural forests to perennial plantations or homegardens probably represents a source of atmospheric $\mathrm{CO}_{2}$ despite their structural resemblance to natural forests. 


\section{Conclusions}

At the southern slope of Mt. Kilimanjaro, the annual pattern of litterfall depends on seasonal climatic conditions. Seasonality at lower elevations leads to a distinct peak of litter production in the late dry season (August-October) that is less pronounced at higher elevations. Annual leaf litter production decreased at higher elevations due to lower temperatures and reduced primary production. Nonetheless, other litter components (branches and rest) mask this effect and total annual litterfall was independent of climate and land-use.
Conversion of natural forests to sustainably or intensively used agroforestry systems leads to direct (change of dominant species) and indirect (increased nutrient uptake after fertilization) enrichment of macronutrients in leaf litter. The change in litter quality reduces the $\mathrm{C}: \mathrm{N}$ ratio, increases the $\mathrm{C}$ and nutrient turnover rates in soil and thus accelerates the ecosystem $\mathrm{C}$ and nutrient cycles. This is followed by decreased $\mathrm{C}$ stocks in agroecosystems, with consequences to their fertility and ecosystem vulnerability. This calls for considering these effects when addressing land-use change and evaluating the sustainability of agroforestry and plantation management. 


\section{Appendix A}

Table A1. Nutrient content in leaf litter $( \pm \mathrm{SE})$ from six ecosystems at Mt. Kilimanjaro, Tanzania. Superscript letters indicate significant differences between the sites (derived from Kruskal-Wallis Test; $p$ level $\leq 0.05$ ).

\begin{tabular}{|c|c|c|c|c|c|c|}
\hline & $\mathrm{HOMb}$ & HOMa & $\mathrm{COF}$ & FLM & FOC & FPO \\
\hline \multicolumn{7}{|c|}{$(\%$ mass $)$} \\
\hline $\mathrm{C}$ & $49.82 \pm 0.38^{\mathrm{a}}$ & $47.36 \pm 0.43^{\mathrm{b}}$ & $47.97 \pm 0.35^{\mathrm{b}}$ & $47.88 \pm 0.28^{b}$ & $49.09 \pm 0.41^{\mathrm{a}}$ & $48.75 \pm 0.62^{\mathrm{ab}}$ \\
\hline $\mathrm{N}$ & $2.95 \pm 0.14^{\mathrm{a}}$ & $2.83 \pm 0.11^{\mathrm{a}}$ & $2.37 \pm 0.10^{\mathrm{b}}$ & $1.08 \pm 0.08^{\mathrm{d}}$ & $1.56 \pm 0.07^{\mathrm{c}}$ & $1.16 \pm 0.08^{\mathrm{d}}$ \\
\hline $\mathrm{C}: \mathrm{N}$ & $17.09 \pm 0.77^{\mathrm{d}}$ & $16.85 \pm 0.63^{d}$ & $20.40 \pm 0.61^{\mathrm{c}}$ & $44.93 \pm 0.52^{\mathrm{a}}$ & $32.10 \pm 0.40^{b}$ & $42.30 \pm 0.50^{\mathrm{a}}$ \\
\hline \multicolumn{7}{|c|}{$\left(\mathrm{mgg}^{-1}\right)$} \\
\hline $\mathrm{Al}$ & $0.77 \pm 0.12^{\mathrm{ab}}$ & $0.94 \pm 0.17^{\mathrm{ab}}$ & $1.10 \pm 0.18^{\mathrm{ab}}$ & $0.43 \pm 0.18^{c}$ & $1.36 \pm 0.19^{\mathrm{a}}$ & $0.74 \pm 0.19^{b c}$ \\
\hline $\mathrm{Ca}$ & $7.95 \pm 0.26^{\mathrm{a}}$ & $17.77 \pm 1.09^{\mathrm{cd}}$ & $13.65 \pm 1.80^{\mathrm{a}}$ & $6.63 \pm 2.00^{\mathrm{d}}$ & $10.09 \pm 2.18^{b}$ & $9.08 \pm 1.88^{b c}$ \\
\hline $\mathrm{Fe}$ & $0.66 \pm 0.11^{\mathrm{a}}$ & $1.10 \pm 0.29^{\mathrm{a}}$ & $0.82 \pm 0.29^{\mathrm{a}}$ & $0.29 \pm 0.30^{\mathrm{b}}$ & $0.79 \pm 0.30^{\mathrm{a}}$ & $0.72 \pm 0.29^{b}$ \\
\hline $\mathrm{K}$ & $15.83 \pm 1.51^{\mathrm{a}}$ & $7.36 \pm 2.45^{\mathrm{b}}$ & $12.87 \pm 2.78^{\mathrm{ab}}$ & $3.08 \pm 3.12^{\mathrm{c}}$ & $3.89 \pm 3.09^{c}$ & $7.17 \pm 2.29^{b}$ \\
\hline $\mathrm{Mg}$ & $1.99 \pm 0.05^{\mathrm{bc}}$ & $3.99 \pm 0.24^{\mathrm{a}}$ & $2.14 \pm 0.34^{\mathrm{bc}}$ & $1.86 \pm 0.33^{\mathrm{cd}}$ & $2.70 \pm 0.41^{\mathrm{a}}$ & $1.47 \pm 0.38^{\mathrm{d}}$ \\
\hline $\mathrm{Mn}$ & $0.11 \pm 0.01^{\mathrm{d}}$ & $0.12 \pm 0.01^{\mathrm{d}}$ & $0.21 \pm 0.01^{\mathrm{c}}$ & $0.52 \pm 0.01^{b}$ & $0.67 \pm 0.01^{\mathrm{ab}}$ & $0.82 \pm 0.01^{\mathrm{a}}$ \\
\hline $\mathrm{Na}$ & $0.22 \pm 0.04^{\mathrm{b}}$ & $0.17 \pm 0.04^{b}$ & $0.22 \pm 0.03^{b}$ & $0.41 \pm 0.03^{\mathrm{a}}$ & $0.60 \pm 0.03^{\mathrm{a}}$ & $0.21 \pm 0.03^{b}$ \\
\hline $\mathrm{P}$ & $1.37 \pm 0.09^{\mathrm{ab}}$ & $1.70 \pm 0.07^{\mathrm{a}}$ & $1.15 \pm 0.05^{\mathrm{b}}$ & $0.67 \pm 0.05^{\mathrm{c}}$ & $0.77 \pm 0.09^{c}$ & $0.74 \pm 0.15^{\mathrm{c}}$ \\
\hline S & $1.98 \pm 0.05^{\mathrm{a}}$ & $1.68 \pm 0.08^{\mathrm{ab}}$ & $1.59 \pm 0.09^{b}$ & $1.06 \pm 0.10^{\mathrm{cd}}$ & $1.19 \pm 0.10^{\mathrm{c}}$ & $0.89 \pm 0.12^{\mathrm{d}}$ \\
\hline
\end{tabular}


Author contributions. J. Mnyonga, H. Pabst and Y. Kuzyakov designed the study. J. Becker, J. Mnyonga and H. Pabst performed the research and J. Becker analyzed the data. J. Becker wrote the paper with contributions of all co-authors.

Acknowledgements. This study was funded by the German Research Foundation (DFG) within the Research-Unit 1246 (KiLi). The authors thank the Tanzanian Commission for Science and Technology (COSTECH), the Tanzania Wildlife Research Institute (TAWIRI) and the Mount Kilimanjaro National Park (KINAPA) for their support. Further thank goes to Andreas Hemp (University of Bayreuth) for selecting the project research sites as well as to our local assistant Ayubu Mtaturu for sampling and maintaining our litter traps.

This open-access publication was funded by the University of Göttingen.

Edited by: A. Ito

\section{References}

Allison, S. D. and Vitousek, P. M.: Rapid nutrient cycling in leaf litter from invasive plants in Hawai'i, Oecologia, 141, 612-619, doi:10.1007/s00442-004-1679-z, 2004.

Appelhans, T., Mwangomo, E., Otte, I., Detsch, F., Nauss, T., and Hemp, A.: Monthly and annual climate data averaged from 2011 to 2013 for 79 research plots on the southern slopes of Mt. Kilimanjaro - V 1.0, Dataset, ZENODO, doi:10.5281/zenodo.11695, 2014.

Barlow, J., Gardner, T. A., Ferreira, L. V., and Peres, C. A.: Litter fall and decomposition in primary, secondary and plantation forests in the Brazilian Amazon, Forest Ecol. Manag., 247, 9197, doi:10.1016/j.foreco.2007.04.017, 2007.

Beer, J.: Litter production and nutrient cycling in coffee (Coffea arabica) or cacao (Theobroma cacao) plantations with shade trees, Agroforest. Syst., 7, 103-114, doi:10.1007/BF00046846, 1988.

Beniston, M.: Climatic Change in Mountain Regions: A Review of Possible Impacts, in: Climate Variability and Change in High Elevation Regions: Past, Present \& Future, edited by: Beniston, M. and Diaz, H. F., Adv. in Glob. Change Res., Springer, the Netherlands, Dordrecht, 5-31, 2003.

Blagodatskaya, E. V., Blagodatsky, S. A., Anderson, T.-H., and Kuzyakov, Y.: Contrasting effects of glucose, living roots and maize straw on microbial growth kinetics and substrate availability in soil, Eur. J. Soil Sci., 60, 186-197, doi:10.1111/j.13652389.2008.01103.x, 2009.

Bonan, G. B.: Forests and Climate Change: Forcings, Feedbacks, and the Climate Benefits of Forests, Science, 320, 1444-1449, doi:10.1126/science.1155121, 2008.

Brown, S.: Tropical forests and the global carbon cycle: the need for sustainable land-use patterns, Agr. Ecosyst. Environ., 46, 31-44, doi:10.1016/0167-8809(93)90011-D, 1993.

Carnol, M. and Bazgir, M.: Nutrient return to the forest floor through litter and throughfall under 7 forest species after conversion from Norway spruce, Forest Ecol. Manag., 309, 66-75, doi:10.1016/j.foreco.2013.04.008, 2013.
Celentano, D., Zahawi, R. A., Finegan, B., Ostertag, R., Cole, R. J., and Holl, K. D.: Litterfall Dynamics Under Different Tropical Forest Restoration Strategies in Costa Rica, Biotropica, 43, 279 287, doi:10.1111/j.1744-7429.2010.00688.x, 2011.

Chave, J., Navarrete, D., Almeida, S., Álvarez, E., Aragão, L. E. O. C., Bonal, D., Châtelet, P., Silva-Espejo, J. E., Goret, J.-Y., von Hildebrand, P., Jiménez, E., Patiño, S., Peñuela, M. C., Phillips, O. L., Stevenson, P., and Malhi, Y.: Regional and seasonal patterns of litterfall in tropical South America, Biogeosciences, 7, 43-55, doi:10.5194/bg-7-43-2010, 2010.

Dawoe, E. K., Isaac, M. E., and Quashie-Sam, J.: Litterfall and litter nutrient dynamics under cocoa ecosystems in lowland humid Ghana, Plant Soil, 330, 55-64, doi:10.1007/s11104-009-0173-0, 2010.

Dawson, J. B.: Neogene tectonics and volcanicity in the North Tanzania sector of the Gregory Rift Valley: contrasts with the Kenya sector, Tectonophysics, 204, 81-92, doi:10.1016/00401951(92)90271-7, 1992.

de Blécourt, M., Brumme, R., Xu, J., Corre, M. D., Veldkamp, E., and Bond-Lamberty, B.: Soil Carbon Stocks Decrease following Conversion of Secondary Forests to Rubber (Hevea brasiliensis) Plantations, PLoS ONE, 8, e69357, doi:10.1371/journal.pone.0069357, 2013.

Debusk, W. F. and Reddy, K. R.: Litter Decomposition and Nutrient Dynamics in a Phosphorus Enriched Everglades Marsh, Biogeochemistry, 75, 217-240, doi:10.1007/s10533-004-7113-0, 2005.

de Mendiburu, F.: Agricolae: Statistical Procedures for Agricultural Research, R package version 1.2-1, available at: http: //CRAN.R-project.org/package=agricolae (last access: 12 July 2015), 2014.

Dent, D. H., Bagchi, R., Robinson, D., Majalap-Lee, N., and Burslem, D. F. R. P.: Nutrient fluxes via litterfall and leaf litter decomposition vary across a gradient of soil nutrient supply in a lowland tropical rain forest, Plant Soil, 288, 197-215, doi:10.1007/s11104-006-9108-1, 2006.

Don, A., Schumacher, J., and Freibauer, A.: Impact of tropical landuse change on soil organic carbon stocks - a meta-analysis, Glob. Change Biol., 17, 1658-1670, doi:10.1111/j.13652486.2010.02336.x, 2011.

Ensslin, A., Rutten, G., Pommer, U., Zimmermann, R., Hemp, A., and Fischer, M.: Effects of elevation and land use on the biomass of trees, shrubs and herbs at Mount Kilimanjaro, Ecosphere, 6, 45, doi:10.1890/ES14-00492.1, 2015.

FAO: Global Forest Resources Assessment 2010, Main report, Rome, 378 pp., 2010.

Fernandes, E., Oktingati, A., and Maghembe, J.: The Chagga homegardens: a multistoried agroforestry cropping system on Mt. Kilimanjaro (Northern Tanzania), Agroforest. Syst., 2, 73-86, 1986.

Fisher, B.: African exception to drivers of deforestation, Nat. Geosci., 3, 375-376, doi:10.1038/ngeo873, 2010.

Fisher, J. B., Malhi, Y., Torres, I. C., Metcalfe, D. B., Weg, M. J., Meir, P., Silva-Espejo, J. E., and Huasco, W. H.: Nutrient limitation in rainforests and cloud forests along a 3,000-m elevation gradient in the Peruvian Andes, Oecologia, 172, 889-902, doi:10.1007/s00442-012-2522-6, 2013.

Fontes, A. G., Gama-Rodrigues, A. C., Gama-Rodrigues, E. F., Sales, M. V. S., Costa, M. G., and Machado, R. C. R.: Nutrient stocks in litterfall and litter in cocoa agroforests in Brazil, Plant Soil, 383, 313-335, doi:10.1007/s11104-014-2175-9, 2014. 
Forrester, D. I., Bauhus, J., and Cowie, A. L.: Nutrient cycling in a mixed-species plantation of Eucalyptus globulus and Acacia mearnsii, Can. J. For. Res., 35, 2942-2950, doi:10.1139/x05-214, 2005.

Girardin, C. A. J., Malhi, Y., Aragão, L. E. O. C., Mamani, M., Huaraca Huasco, W., Durand, L., Feeley, K. J., Rapp, J., Silva-Espejo, J. E., Silman, M., Salinas, N., and Whittaker, R. J.: Net primary productivity allocation and cycling of carbon along a tropical forest elevational transect in the Peruvian Andes, Glob. Change Biol., 16, 3176-3192, doi:10.1111/j.13652486.2010.02235.x, 2010.

González-Rodríguez, H., Domínguez-Gómez, T. G., Cantú-Silva, I., Gómez-Meza, M. V., Ramírez-Lozano, R. G., Pando-Moreno, M., and Fernández, C. J.: Litterfall deposition and leaf litter nutrient return in different locations at Northeastern Mexico, Plant Ecol., 212, 1747-1757, doi:10.1007/s11258-011-9952-9, 2011.

Grandy, A. S., Salam, D. S., Wickings, K., McDaniel, M. D., Culman, S. W., and Snapp, S. S.: Soil respiration and litter decomposition responses to nitrogen fertilization rate in no-till corn systems, Agr. Ecosyst. Environ., 179, 35-40, doi:10.1016/j.agee.2013.04.020, 2013.

Groffman, P. M., McDowell, W. H., Myers, J. C., and Merriam, J. L.: Soil microbial biomass and activity in tropical riparian forests, Soil Biol. Biochem., 33, 1339-1348, doi:10.1016/S00380717(01)00039-6, 2001.

Groombridge, B. and Jenkins, M. D.: World Atlas of Biodiversity, Prepared by the UNEP World Conservation Monitoring Centre, University of California Press, Berkeley, Los Angeles, London, 2002.

Hansen, M. C., Stehman, S. V., and Potapov, P. V.: Quantification of global gross forest cover loss, P. Natl. Acad. Sci. USA, 107, 8650-8655, doi:10.1073/pnas.0912668107, 2010.

Hemp, A.: Continuum or zonation? Altitudinal gradients in the forest vegetation of Mt. Kilimanjaro, Plant Ecol., 184, 27-42, doi:10.1007/s11258-005-9049-4, 2006a.

Hemp, A.: The Banana Forests of Kilimanjaro: Biodiversity and Conservation of the Chagga Homegardens, Biodivers. Conserv., 15, 1193-1217, doi:10.1007/s10531-004-8230-8, 2006b.

Homeier, J., Hertel, D., Camenzind, T., Cumbicus, N. L., Maraun, M., Martinson, G. O., Poma, L. N., Rillig, M. C., Sandmann, D., Scheu, S., Veldkamp, E., Wilcke, W., Wullaert, H., and Leuschner, C.: Tropical Andean forests are highly susceptible to nutrient inputs - rapid effects of experimental $\mathrm{N}$ and $\mathrm{P}$ addition to an Ecuadorian montane forest, PLoS ONE, 7, e47128, doi:10.1371/journal.pone.0047128, 2012.

Katz, M. H.: Study design and statistical analysis: A practical guide for clinicians, Cambridge University Press, Cambridge, 188, 2006.

Khan, S. A., Mulvaney, R. L., Ellsworth, T. R., and Boast, C. W.: The myth of nitrogen fertilization for soil carbon sequestration, J. Environ. Qual., 36, 1821-1832, doi:10.2134/jeq2007.0099, 2007.

Kluge, J., Kessler, M., and Dunn, R. R.: What drives elevational patterns of diversity? A test of geometric constraints, climate and species pool effects for pteridophytes on an elevational gradient in Costa Rica, Global Ecol. Biogeogr., 15, 358-371, doi:10.1111/j.1466-822X.2006.00223.x, 2006.
Köhler, L., Hölscher, D., and Leuschner, C.: High litterfall in oldgrowth and secondary upper montane forest of Costa Rica, Plant Ecol., 199, 163-173, doi:10.1007/s11258-008-9421-2, 2008.

Lambrechts, C., Woodley, B., Hemp, A., Hemp, C., and Nnyiti, P.: Aerial Survey of the Threats to Mt. Kilimanjaro Forests, United Nations Development Programme, Dar es Salaam, 2002.

Lewis, S. L.: Tropical forests and the changing earth system, Philos. T. R. Soc. B, 361, 195-210, doi:10.1098/rstb.2005.1711, 2006.

Lisanework, N. and Michelsen, A.: Litterfall and nutrient release by decomposition in three plantations compared with a natural forest in the Ethiopian highland, Forest Ecol. Manag., 65, 149_ 164, doi:10.1016/0378-1127(94)90166-X, 1994.

Lu, S.-W. and Liu, C.-P.: Patterns of litterfall and nutrient return at different altitudes in evergreen hardwood forests of Central Taiwan, Ann. For. Sci., 69, 877-886, doi:10.1007/s13595-0120213-4, 2012.

Meier, I. C., Leuschner, C., and Hertel, D.: Nutrient return with leaf litter fall in Fagus sylvatica forests across a soil fertility gradient, Plant Ecol., 177, 99-112, doi:10.1007/s11258-005-2221-z, 2005.

Mganga, K. Z. and Kuzyakov, Y.: Glucose decomposition and its incorporation into soil microbial biomass depending on land use in Mt. Kilimanjaro ecosystems, Eur. J. Soil Biol., 62, 74-82, doi:10.1016/j.ejsobi.2014.02.015, 2014.

Misana, S. B., Sokoni, C., and Mbonile, M. J.: Land-use/cover changes and their drivers on the slopes of Mount Kilimanjaro, Tanzania, J. Geogr. Reg. Plann., 5, 151-164, doi:10.5897/JGRP11.050, 2012.

Mölg, T., Chiang, John C. H., Gohm, A., and Cullen, N. J.: Temporal precipitation variability versus altitude on a tropical high mountain: Observations and mesoscale atmospheric modelling, Q. J. Roy. Meteor. Soc., 135, 1439-1455, doi:10.1002/qj.461, 2009.

O'Connell, A. M. and Grove, T. S.: Influence of nitrogen and phosphorus fertilizers on amount and nutrient content of litterfall in a regrowth eucalypt forest, New Forest, 7, 33-47, doi:10.1007/BF00037470, 1993.

Okeke, A. I. and Omaliko, C.: Litterfall and seasonal patterns of nutrient accumulation in Dactyladenia barteria (Hook f ex. Oliv.) Engl. bush fallow at Ozala, Nigeria, Forest Ecol. Manag., 67, 345-351, doi:10.1016/0378-1127(94)90029-9, 1994.

Pabst, H., Kühnel, A., and Kuzyakov, Y.: Effect of land-use and elevation on microbial biomass and water extractable carbon in soils of Mt. Kilimanjaro ecosystems, Appl. Soil Ecol., 67, 10-19, doi:10.1016/j.apsoil.2013.02.006, 2013.

Pabst, H.: Factors controlling microbial biomass in soils of Mt. Kilimanjaro, Dissertation, Faculty of Biology, Chemistry and Earth Sciences, University of Bayreuth, Germany, 130 pp., 2015.

Qiu, S., McComb, A., Bell, R., and Davis, J.: Leaf-litter application to a sandy soil modifies phosphorus leaching over the wet season of southwestern Australia, Hydrobiologia, 545, 33-44, doi:10.1007/s10750-005-1826-5, 2005.

R Core Team: R: A language and environment for statistical computing, R Foundation for Statistical Computing, Vienna, Austria, 2013.

Röderstein, M., Hertel, D., and Leuschner, C.: Above- and below-ground litter production in three tropical montane forests in southern Ecuador, J. Trop. Ecol., 21, 483-492, doi:10.1017/S026646740500249X, 2005. 
Rutten, G., Ensslin, A., Hemp, A., and Fischer, M.: Forest structure and composition of previously selectively logged and non-logged montane forests at Mt. Kilimanjaro, Forest Ecol. Manag., 337, 61-66, doi:10.1016/j.foreco.2014.10.036, 2015.

Saugier, B., Roy, J., and Mooney, H. A.: Estimations of global terrestrial productivity: Converging toward a single number?, in: Terrestrial Global Productivity, edited by: Roy, J., Saugier, B., and Mooney, H. A., Academic Press, San Diego, CA, USA, 543557, 2001.

Sayer, E. J., Powers, J. S., Tanner, Edmund V. J., and Chave, J.: Increased Litterfall in Tropical Forests Boosts the Transfer of Soil $\mathrm{CO}_{2}$ to the Atmosphere, PLoS ONE, 2, e1299, doi:10.1371/journal.pone.0001299, 2007.

Sayer, E. J., Heard, M. S., Grant, H. K., Marthews, T. R., and Tanner, Edmund V. J.: Soil carbon release enhanced by increased tropical forest litterfall, Nature Climate change, 1, 304-307, doi:10.1038/NCLIMATE1190, 2011.

Schrumpf, M., Zech, W., Axmacher, J. C., and Lyaruu, Herbert V. M.: Biogeochemistry of an afrotropical montane rain forest on Mt. Kilimanjaro, Tanzania, J. Trop. Ecol., 22, 77-89, doi:10.1017/S0266467405002907, 2006.

Selva, E. C., Couto, E. G., Johnson, M. S., and Lehmann, J.: Litterfall production and fluvial export in headwater catchments of the southern Amazon, J. Trop. Ecol., 23, 329-335, doi:10.1017/S0266467406003956, 2007.

Sharma, S. C. and Pande, P. K.: Patterns of litter nutrient concentration in some plantation ecosystems, Forest Ecol. Manag., 29, 151-163, doi:10.1016/0378-1127(89)90046-7, 1989.

UCS: The Root of the Problem: What's driving tropical deforestation today, UCS Publications, Cambridge, MA, 2011.

Vasconcelos, S. S., Zarin, D. J., Araújo, M. M., RangelVasconcelos, L. G. T., de Carvalho, C. J. R., Staudhammer, C. L., and Oliveira, F. A.: Effects of seasonality, litter removal and dry-season irrigation on litterfall quantity and quality in eastern Amazonian forest regrowth, Brazil, J. Trop. Ecol., 24, 884-892, doi:10.1017/S0266467407004580, 2008.
Vitousek, P. M.: Litterfall, Nutrient Cycling, and Nutrient Limitation in Tropical Forests, Ecology, 65, 285-298, 1984.

Vitousek, P. M. and Sanford, R. L.: Nutrient Cycling in Moist Tropical Forest, Annu. Rev. Ecol. Syst., 17, 137-167, 1986.

Wickham, H.: ggplot2: Elegant Graphics for Data Analysis, Springer, New York, NY, 210 pp., 2009.

Yang, Y. S., Guo, J. F., Chen, G. S., Xie, J. S., Cai, L. P., and Lin, P.: Litterfall, nutrient return, and leaf-litter decomposition in four plantations compared with a natural forest in subtropical China, Ann. For. Sci., 61, 465-476, doi:10.1051/forest:2004040, 2004.

Zech, M.: Evidence for Late Pleistocene climate changes from buried soils on the southern slopes of Mt. Kilimanjaro, Tanzania, Palaeogeography, Palaeoclimatology, Palaeoecology, 242, 303312, doi:10.1016/j.palaeo.2006.06.008, 2006.

Zech, M., Bimüller, C., Hemp, A., Samimi, C., Broesike, C., Hörold, C., Zech, W.: Human and climate impact on $15 \mathrm{~N}$ natural abundance of plants and soils in high-mountain ecosystems: a short review and two examples from the Eastern Pamirs and Mt. Kilimanjaro, Isotopes in Environmental and Health Studies, 47, 286-296, doi:10.1080/10256016.2011.596277, 2011.

Zech, M., Hörold, C., Leiber-Sauheitl, K., Kühnel, A., Hemp, A., and Zech, W.: Buried black soils on the slopes of Mt. Kilimanjaro as a regional carbon storage hotspot, CATENA, 112, 125-130, doi:10.1016/j.catena.2013.05.015, 2014.

Zhang, H., Yuan, W., Dong, W., Liu S.: Seasonal patterns of litterfall in forest ecosystem worldwide, Ecological Complexity, 20, 240247, doi:10.1016/j.ecocom.2014.01.003, 2014.

Zhou, G., Guan, L., Wei, X., Zhang, D., Zhang, Q., Yan, J., Wen, D., Liu, J., Liu, S., Huang, Z., Kong, G., Mo, J., and Yu, Q.: Litterfall Production Along Successional and Altitudinal Gradients of Subtropical Monsoon Evergreen Broadleaved Forests in Guangdong, China, Plant Ecol, 188, 77-89, doi:10.1007/s11258006-9149-9, 2006. 